\title{
Compressive Strength and Microstructure Properties of Alkali-Activated Systems with Blast Furnace Slag, Desulfurization Slag, and Gypsum
}

\author{
Bong-Suk Cho $\mathbb{D D}^{1},{ }^{1}$ Kyung-Mo Koo $\mathbb{I D}^{2},{ }^{2}$ and Se-Jin Choi ${ }^{3}{ }^{3}$ \\ ${ }^{1}$ Principal Researcher, Environment and Resources Research Group, Research Institute of Industrial Science and Technology, \\ Pohang 37673, Republic of Korea \\ ${ }^{2}$ Assistant Manager, Support Planning Division R\&D Center, ASIA Cement Co, Yongin, Republic of Korea \\ ${ }^{3}$ Professor, Department of Architectural Engineering, Wonkwang University, 460 Iksan-daero, Iksan 54538, Republic of Korea
}

Correspondence should be addressed to Se-Jin Choi; csj2378@wku.ac.kr

Received 21 July 2018; Accepted 30 October 2018; Published 11 December 2018

Academic Editor: Flora Faleschini

Copyright ( 92018 Bong-Suk Cho et al. This is an open access article distributed under the Creative Commons Attribution License, which permits unrestricted use, distribution, and reproduction in any medium, provided the original work is properly cited.

\begin{abstract}
This study investigates the effect of desulfurization slag (DS) and gypsum (G) on the compressive strength and microstructure properties of blast furnace slag-(BFS-) based alkali-activated systems. DS is produced in a Kambara reactor process of molten iron produced in a steel production process. DS contains $\mathrm{CaO}, \mathrm{SiO}_{2}, \mathrm{Fe}_{2} \mathrm{O}_{3}$, and $\mathrm{SO}_{3}$ and is composed of $\mathrm{Ca}(\mathrm{OH})_{2}$ and $2 \mathrm{CaO} \cdot \mathrm{SiO}{ }_{2}$ as main compounds. In this investigation, the weight of BFS was replaced by DS at 5, 10, 15, 20, 25, and 30\%. In addition, G was also applied at 9,12 , and $15 \%$ by weight of BFS to improve the compressive strength of the alkali-activated system with BFS and DS. According to this investigation, the compressive strength of the alkali-activated mixes with BFS and DS ranged from $14.9 \mathrm{MPa}$ (B95D5) to $19.8 \mathrm{MPa}$ (B90D10) after 91 days. However, the 28 days compressive strength of the alkali-activated mixes with BFS, DS, and G reached 39.1 MPa, 45.2 MPa, and 48.4 MPa, respectively, which were approximately 78.8 to $97.5 \%$ of that of O100 mix $(49.6 \mathrm{MPa})$. The main hydrates of the BFS-DS (B80D20) binder sample were $\mathrm{Ca}(\mathrm{OH})_{2}, \mathrm{CaCO}_{3}$, and low-crystalline calcium silicate hydrates, while the main hydration product of BFS-DS-G (B75D10G15) binder was found as ettringite. The use of BFS-DS-G binders would result in the value-added utilization of steel slag and provide an environmentally friendly construction material, and contribute to a reduction of $\mathrm{CO}_{2}$ in the cement industry.
\end{abstract}

\section{Introduction}

When producing 1 ton of ordinary Portland cement (OPC), approximately $900 \mathrm{~kg}$ of $\mathrm{CO}_{2}$ is generated. Recognizing the sustainability of the environment as a top priority, many studies for reducing the amount of $\mathrm{CO}_{2}$ generated by cement production and reducing energy consumption are reported [1-4]. As part of this, various efforts have been made to reduce the amount of OPC by increasing the amount of cementitious materials for concrete such as fly ash, blast furnace slag (BFS), and limestone powder [5-7]. In addition, many studies have been actively made on alkali-activated systems, which can be hardened without containing cement. These alkali-activated systems can be hardened without cement by incorporating an alkaline activator into cementitious materials rich in $\mathrm{CaO}$ and $\mathrm{SiO}_{2}$, such as $\mathrm{BFS}$, fly ash, metakaolin, and kaolinite clays [8-12]. In the case of the $\mathrm{BFS}$, the incorporation of an alkali activator into the BFS facilitates the elution of $\mathrm{Ca}^{2+}, \mathrm{Si}^{4+}$, and $\mathrm{Al}^{3+}$ from the BFS, allowing calcium silicate hydrates $(\mathrm{C}-\mathrm{S}-\mathrm{H})$ and calcium aluminum hydrates (C-A-H) [13-16]. For alkali activation in alkali-activated systems, $\mathrm{NaOH}, \mathrm{Na}_{2} \mathrm{SiO}_{3}$, and $\mathrm{KOH}$, which are based on alkali metals such as sodium $(\mathrm{Na})$ and potassium (K), have been mainly used in many studies [2, 17-21]. Although Na- and K-type alkali activators contribute to the formation of high concentration of hydroxide ions $(\mathrm{OH}-)$, which leads to quick setting in a short time, some disadvantages such as high cost, high toxicity (with a $\mathrm{pH}$ of 14 or higher), and alkali silica reaction have also been reported [22-24]. 
In this study, we investigated the applicability of desulfurization slag (DS) as an alkali activator of an alkaliactivated system. DS is produced in a Kambara reactor process of molten iron produced in a steel production process. In general, molten iron contains a small amount of sulfur $(0.1-0.5 \%)$, and it has a negative effect on the quality of steel product. Therefore, the desulfurization process is required to reduce the sulfur amount by approximately below $0.05 \%$.

In this process, mechanical stirring is performed after the addition of a desulfurizing agent $(\mathrm{CaO})$. Sulfur in molten iron reacts with $\mathrm{CaO}$ to form CaS-type compounds including $\mathrm{CaS}$ and $\mathrm{CaSO}_{4}$. Because the reaction rate of $\mathrm{CaO}$ is $30 \%$ or less, unreacted $\mathrm{CaO}$ remains. The specific gravity of $\mathrm{CaS}$ compound and unreacted $\mathrm{CaO}$ is low; therefore, they float to the top of the molten steel and mix into the slag layer. The slag produced in the desulfurization process is DS $[25,26]$.

The DS filled in a moving pot is transferred to the cooling yard. Next, water is sprayed to control scattering dust and achieve rapid cooling. After the water spraying, iron is recovered from the slag through the process of crushing and magnetic separation. The recovered iron is recycled as a substitute for iron ore or scrap in the iron and steelmaking process. The nonmagnetic DS, the final remnant in the process, consists of sand-shaped grains with a diameter of $2 \mathrm{~mm}$ or less. It is used only for road base or landfill with a mixture of a convert slag. Korean steel makers generate up to about 300,000 ton/year of the nonmagnetic DS, but it has not yet been utilized except as materials for civil works.

Since DS is cooled by water spray, most of $\mathrm{CaO}$ is converted to $\mathrm{Ca}(\mathrm{OH})_{2}$, which dissolves in water with $\mathrm{Ca}^{2+}$ and $2 \mathrm{OH}^{-}$to form a high $\mathrm{pH}$ environment. In this study, the compressive strength and microstructure characteristics of alkali-activated BFS-based systems using DS and gypsum $(\mathrm{G})$ as activators were examined. The ultimate goal of this study is to show that DS, an industrial byproduct, can be used more effectively and efficiently in alkali-activated systems.

\section{Materials and Methods}

2.1. Materials. ASTM type I OPC was used. BFS, DS, and G (natural anhydrous gypsum) were used as constituents of the alkali-activated system. The BFS was used as the powdered product.

In addition, the mix with only OPC and the mix with $50 \%$ OPC and 50\% BFS were used for performance comparison of the alkali-activated system. DS was produced from P Company of Korea, and the Blaine Fineness was $404 \mathrm{~m}^{2} / \mathrm{kg}$, whereas those for the OPC, G, and BFS used in this study were 341,433 , and $453 \mathrm{~m}^{2} / \mathrm{kg}$, respectively.

The chemical composition is presented in Table 1.

The mortar specimen for the compressive strength test was manufactured with ISO standard sand (KS L ISO 679, standard sand for strength measurement) as indicated in Table 2 . The absorption and specific gravity of ISO sand were $1.03 \%$ and $2.54 \mathrm{~g} / \mathrm{cm}^{3}$, respectively.
2.2. Mix Proportions and Specimen Preparation. Table 3 presents the experimental plan of this study. For the weight of BFS, DS was applied at 5, 10, 15, 20, 25, and 30\%. In addition, $G$ was also applied at 9,12 , and $15 \%$ by BFS weight to improve the compressive strength of the alkaliactivated system with BFS and DS. The weight ratio of water:sand:binder in the mortar for evaluating compressive strength of the mixes was $0.5: 3: 1$. The compressive strength of the mortar was measured in compliance with ASTM C349. The mortar specimen with dimensions of $40 \times 40 \times 160 \mathrm{~mm}$ was made using a jolting machine and water cured at $20 \pm 2{ }^{\circ} \mathrm{C}$. Then, the compressive strength of the specimen was measured at $3,7,28$, 56 , and 91 days [27].

The water-binder ratio of the samples prepared for the microstructure property including hydration heat, X-ray diffraction (XRD), scanning electron microscopy (SEM), and porosity analyses was 0.5 .

The hydration heat was measured for 7 days at intervals of $30 \mathrm{~s}$ using a calorimeter (MMC-511SV6, Tokyo Rico Corp.). The specimens were microstructurally studied by XRD (D/Max-2500V, Rigaku Corp.) and SEM (S-4300SE, Hitachi Corp.) at 28 days. In addition, a mercury intrusion porosimetry (MIP) test (ASTM D 4284) was performed to evaluate the microporous structure $[28,29]$.

\section{Results and Discussion}

3.1. Chemical Properties of Raw Materials. Figure 1 shows the XRD patterns and SEM images of the raw materials used in this study. DS contains $\mathrm{CaO}, \mathrm{SiO}_{2}, \mathrm{Fe}_{2} \mathrm{O}_{3}$, and $\mathrm{SO}_{3}$ and is composed of $\mathrm{Ca}(\mathrm{OH})_{2}$. and $2 \mathrm{CaO} \cdot \mathrm{SiO}_{2}$ as main compounds. Since water is sprayed during the cooling process, the unreacted $\mathrm{CaO}$, which was added as a desulfurizing agent, is transferred to $\mathrm{Ca}(\mathrm{OH})_{2}$. The $\mathrm{Ca}(\mathrm{OH})_{2}$ content in DS calculated by thermogravimetric analysis was approximately 25$30 \%$. $\mathrm{SiO}_{2}$ and $\mathrm{Al}_{2} \mathrm{O}_{3}$ contents in DS are significantly lower than those in BFS, but it contains more $\mathrm{CaO}$ and $\mathrm{Fe}_{2} \mathrm{O}_{3}$ than BFS. The XRD patterns of DS show a very high peak of crystalline carbon. In general, cokes are used to separate oxygen from iron ores present as FeOx-type oxides in the steelmaking process. Unburned cokes, which are deoxidizers, also exist in molten iron, and most of the unburned cokes are incorporated into the slag layer. The DS thus contains approximately $4-5 \%$ of coke (a carbon component).

The main peaks of OPC show $3 \mathrm{CaO} \cdot \mathrm{SiO}_{2}$ (alite) and $2 \mathrm{CaO} \cdot \mathrm{SiO}_{2}$ (belite). It also contains small amounts of $3 \mathrm{CaO} \cdot \mathrm{Al}_{2} \mathrm{O}_{3}$ (calcium aluminate) and $4 \mathrm{CaO} \cdot \mathrm{Al}_{2} \mathrm{O}_{3} \cdot \mathrm{Fe}_{2} \mathrm{O}_{3}$ (calcium aluminate ferrite).

The main peak of DS is $\mathrm{Ca}(\mathrm{OH})_{2}$, and it can act as an alkaline activator because it contains an $\mathrm{OH}^{-}$ion. Some peaks of $\mathrm{CaCO}_{3}$ were also found by the drying process but free $\mathrm{CaO}$ was not found in DS. In addition, DS contains the peak of $2 \mathrm{CaO} \cdot \mathrm{SiO}_{2}$ because some $\mathrm{CaO}$ added as a desulfurizing agent reacts with $\mathrm{SiO}_{2}$ present in the slag to form a $\mathrm{CaO}-\mathrm{SiO}_{2}$ compound. The SEM image of DS shows rough surface characteristics because of the presence of $\mathrm{Ca}(\mathrm{OH})_{2}$ and $\mathrm{CaCO}_{3}$ particles formed by the water spray cooling and drying processes. In the case of the SEM image of BFS, an 
TABLe 1: Chemical compositions.

\begin{tabular}{lcccccccccc}
\hline & $\mathrm{CaO}(\%)$ & $\mathrm{SiO}_{2}(\%)$ & $\mathrm{Al}_{2} \mathrm{O}_{3}(\%)$ & $\mathrm{Fe}_{2} \mathrm{O}_{3}(\%)$ & $\mathrm{MgO}(\%)$ & $\mathrm{Na}_{2} \mathrm{O}(\%)$ & $\mathrm{K}_{2} \mathrm{O}(\%)$ & $\mathrm{SO}_{3}(\%)$ & $\mathrm{C}_{(\%)}$ & $\mathrm{Density}_{\left(\mathrm{g} / \mathrm{cm}^{3}\right)}$ \\
\hline OPC (O) & 62.2 & 20.7 & 6.2 & 3.10 & 2.8 & 0.10 & 0.8 & 2.1 & - & 3.15 \\
BFS (B) & 43.5 & 32.8 & 15.6 & 0.50 & 4.41 & 0.25 & 0.49 & 1.04 & - & 2.98 \\
DS (D) & 62.2 & 10.6 & 1.21 & 11.6 & 1.5 & 0.10 & - & 5.2 & 4.1 & 3.01 \\
Gypsum (G) & 41.6 & 0.73 & 0.17 & 0.16 & - & 0.02 & 0.03 & 55.5 & - & 2.93 \\
\hline
\end{tabular}

TABle 2: Sieve analysis of the sand.

\begin{tabular}{lcc}
\hline $\begin{array}{l}\text { Square mesh } \\
\text { size }(\mathrm{mm})\end{array}$ & $\begin{array}{c}\text { Cumulative sieve } \\
\text { residue }(\%)\end{array}$ & Criteria (KS L ISO 679) \\
\hline 2 & 0 & 0 \\
1.6 & 8.2 & $2-12$ \\
1 & 32.7 & $28-38$ \\
0.5 & 68.4 & $62-72$ \\
0.16 & 89.7 & $82-92$ \\
0.08 & 98.8 & $98-100$ \\
\hline
\end{tabular}

TABLe 3: Experimental plan.

\begin{tabular}{lcccc}
\hline Mix. & OPC (O) & BFS (B) & DS (D) & Gypsum (G) \\
\hline O100 & 100 & - & - & - \\
O50B50 & 50 & 50 & - & - \\
B95D5 & - & 95 & 5 & - \\
B90D10 & - & 90 & 10 & - \\
B85D15 & - & 85 & 15 & - \\
B80D20 & - & 80 & 20 & - \\
B75D25 & - & 75 & 25 & - \\
B70D30 & - & 70 & 30 & - \\
B81D10G9 & - & 81 & 10 & 9 \\
B78D10G12 & - & 78 & 10 & 12 \\
B75D10G15 & - & 75 & 10 & 15 \\
\hline
\end{tabular}

amorphous and very smooth surface was found because BFS was cooled through rapid watering in the molten state.

3.2. Compressive Strength. When water is added to the mixture consisting of BFS and DS, $\mathrm{OH}^{-}$ions are eluted from $\mathrm{Ca}(\mathrm{OH})_{2}$ contained in DS. The impermeable film around BFS is destroyed by the alkali activation of $\mathrm{OH}^{-}$ions, and hydration reaction occurs to produce hydration products such as $x \mathrm{CaO}-y \mathrm{SiO}_{2}-z \mathrm{H}_{2} \mathrm{O}$ and $x \mathrm{CaO}-y \mathrm{Al}_{2} \mathrm{O}_{3}-z \mathrm{H}_{2} \mathrm{O}$ [30-32]. Figure 2 shows the compressive strength of alkaliactivated mixes with BFS and DS. At 28 days, the compressive strengths of B95D5, B90D10, B85D15, B80D20, $\mathrm{B} 75 \mathrm{D} 25$, and $\mathrm{B} 70 \mathrm{D} 30$ mixes were measured as $12.1 \mathrm{MPa}$, 15.6 MPa, 15.8 MPa, 16.6 MPa, 14.9 $\mathrm{MPa}$, and 14.0 $\mathrm{MPa}$, respectively. At 56 days, the compressive strengths of the alkali-activated mixes ranged from $14.4 \mathrm{MPa}$ (B95D5) to 18.7 MPa (B90D10). The compressive strengths of the alkaliactivated mixes with BFS and DS ranged from $14.9 \mathrm{MPa}$ (B95D5) to $19.8 \mathrm{MPa}$ (B90D10) after 91 days. When the amount of DS is less than $5 \%$ or more than $20 \%$, the compressive strength of the mixes was lower than that of other mixes. Therefore, the appropriate amount of DS in alkali-activated systems with BFS and DS is considered to be in the range of 10 to $15 \%$. However, the compressive strength of alkali-activated systems with BFS and DS was relatively lower than that of the O100 and O50B50 mixes at all ages. The compressive strength of the alkali-activated systems with BFS and DS was approximately 25 to $36 \%$ of that of O100 and O50B50 at 91 days.

In order to improve such low compressive strengths, the anhydrous $\mathrm{G}$ was applied in this study. Generally, it is considered that $\mathrm{CaSO}_{4}$ can contribute to the formation of needle-shaped ettringite $\left(3 \mathrm{CaO} \cdot \mathrm{Al}_{2} \mathrm{O}_{3} \cdot 3 \mathrm{CaSO}_{4} \cdot 32 \mathrm{H}_{2} \mathrm{O}\right)$, which can decrease the porosity by packing micropores [33-35].

Figure 3 shows the variation in compressive strength of alkali-activated mixes consisting of BFS, DS, and G. The amount of DS was $10 \%$, which was considered to prevent reduction of the workability through preliminary experiments, and the G was used to replace BFS at replacement ratios of 9,12 , and $15 \%$ by binder mass.

At 3 and 7 days, the compressive strength of alkaliactivated mixes with BFS, DS, and G was lower than that of $\mathrm{O} 100$ and O50B50 mixes. However, the 28 days compressive strengths of B81D10G9, B78D10G12, and B75D10G15 mixes reached $39.1 \mathrm{MPa}, 45.2 \mathrm{MPa}$, and $48.4 \mathrm{MPa}$, respectively, which were approximately 78.8 to $97.5 \%$ of that of O100 mix (49.6 MPa). After 56 days, the increase in compressive strength of alkali-activated mixes with BFS, DS, and $\mathrm{G}$ appeared to be insignificant.

Figure 4 shows the relative compressive strength ratios of the alkali-activated mixes compared to that of O100 mix. In the case of the alkali-activated mixes with BFS and DS, the compressive strength was approximately 20 to $30 \%$ of that of $\mathrm{O} 100$ mix. In addition, it was found that the growth rate of compressive strength of the mixes according to age was very low. However, the increase in compressive strength of the alkali-activated mixes with BFS, DS, and G was noticeable until 28 days. In particular, the compressive strength ratios of B75D10G15 mix at 28,56, and 91 days were $97.6 \%$, $106.3 \%$, and $104.1 \%$, respectively, of those of O100 mix. The compressive strength ratios of B78D10G12 mix at 28, 56, and 91 days were $91.1 \%, 97.9 \%$, and $97.8 \%$, respectively, compared to those of $\mathrm{O} 100 \mathrm{mix}$. Therefore, the addition of $\mathrm{G}$ to the alkali-activated mixes with BFS and DS made it possible to produce alkali-activated systems that can increase the compressive strength by approximately 3 times compared to the alkali-activated mixes consisting of BFS and DS. It seems that it is possible to produce alkali-activated systems having compressive strengths similar to mixes with OPC.

3.3. Heat of Hydration. Figure 5 shows the variation in hydration heat of the samples. The first peak is an exothermic reaction due to the hydration reaction of water and 


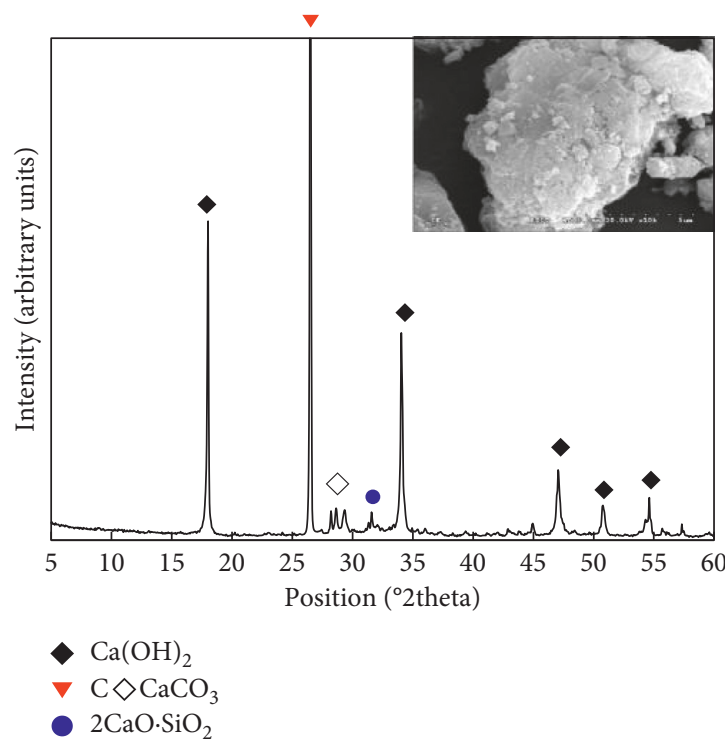

(a)

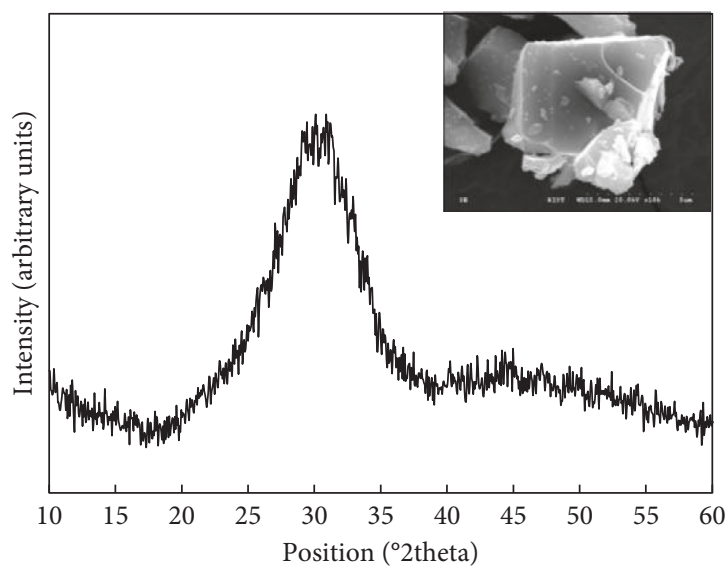

(c)

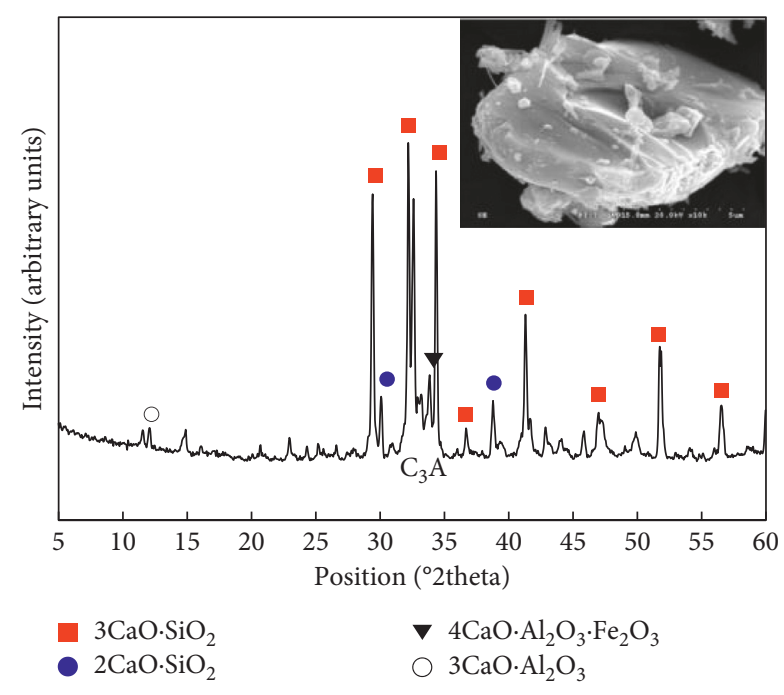

(b)

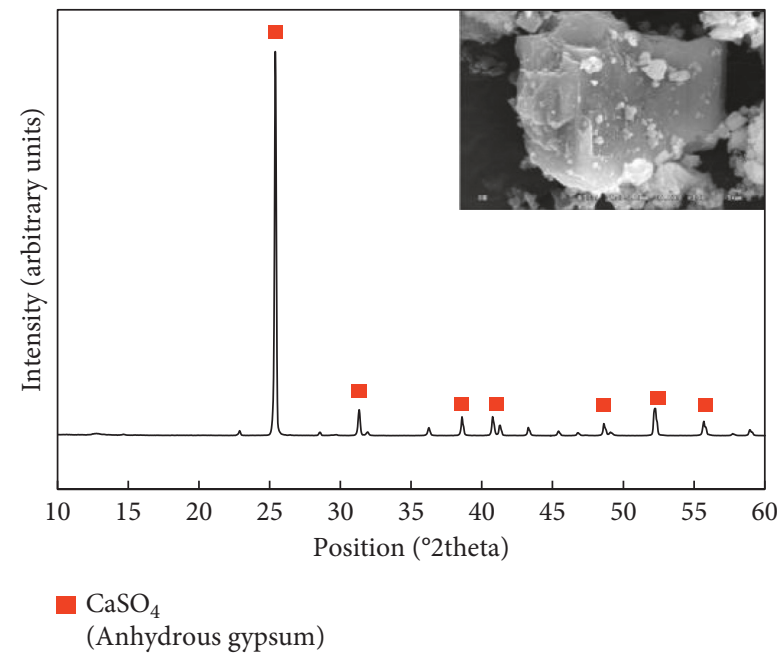

(d)

FIGURE 1: XRD patterns and SEM image of used materials. (a) DS, (b) OPC, (c) BFS, and (d) gypsum.

$3 \mathrm{CaO} \cdot \mathrm{Al}_{2} \mathrm{O}_{3}$ and the formation of ettringite [36, 37]. The first peak appears within approximately $1 \mathrm{~h}$ at all mixes. The heat evolution rates of the first peak of $\mathrm{O} 100$ and O50B50 mixes were measured to be 1.2 and $0.5 \mathrm{~J} / \mathrm{h} \cdot \mathrm{g}$, respectively. The heat evolution rate of the first peak of B80D20 was $0.12 \mathrm{~J} / \mathrm{h} \cdot \mathrm{g}$, and the heat evolution rates of B81D10G9, B78D10G12, and B75D10G15 mixes were in the range of $0.075-0.08 \mathrm{~J} / \mathrm{h} \cdot \mathrm{g}$. These values were much lower compared to those of O100 and O50B50 mixes. The first peak of the alkali-activated mixes with BFS, DS, and G was lower than the alkaliactivated mixes without $\mathrm{G}$.

The second peak means the hydration exothermic reaction of $3 \mathrm{CaO} \cdot \mathrm{SiO}_{2}$. The hydration heat peak of $\mathrm{O} 100 \mathrm{mix}$ appeared between 13 and $14 \mathrm{~h}$, whereas the hydration heat peak of O50B50 mix was between 18 and $19 \mathrm{~h}$. However, the hydration heat peaks of the alkali-activated mixes with BFS, DS, and $\mathrm{G}$ ranged from 26 to $30 \mathrm{~h}$, which were very late compared to those of O100 and O50B50 mixes. In particular, the hydration heat peak of the alkali-activated mix with BFS and DS was not noticeable, which means that the hydration reactivity is very low $[38,39]$.

The cumulative heat releases of O100, O50B50, B75D10G15, B78D10G12, B81D10G9, and B80D20 mixes were $301.4 \mathrm{~J} / \mathrm{g}(100 \%), 211.7 \mathrm{~J} / \mathrm{g}(70.2 \%), 109.4 \mathrm{~J} / \mathrm{g}(36.3 \%)$, $97.9 \mathrm{~J} / \mathrm{g}(32.5 \%), 82.3 \mathrm{~J} / \mathrm{g}(27.3 \%)$, and $69.1 \mathrm{~J} / \mathrm{g}(22.9 \%)$, respectively. Thus, the alkali-activated system with BFS, DS, and $G$ can be useful in lowering the hydration heat when applying mass concrete because its hydration heat is relatively lower compared to that of O100 mix $[28,40,41]$.

3.4. XRD and SEM Analysis. Figure 6 shows the XRD patterns of O100, O50B50, B80D20, and B75D10G15 samples after 28 days. As shown in Figure 6, the main hydrates of $\mathrm{O} 100$ and $\mathrm{O} 50 \mathrm{~B} 50$ samples were $\mathrm{Ca}(\mathrm{OH})_{2}$ and $\mathrm{C}-\mathrm{S}-\mathrm{H}$, and alite $\left(3 \mathrm{CaO} \cdot \mathrm{SiO}_{2}\right)$ and belite $\left(2 \mathrm{CaO} \cdot \mathrm{SiO}_{2}\right)$ peaks were also 


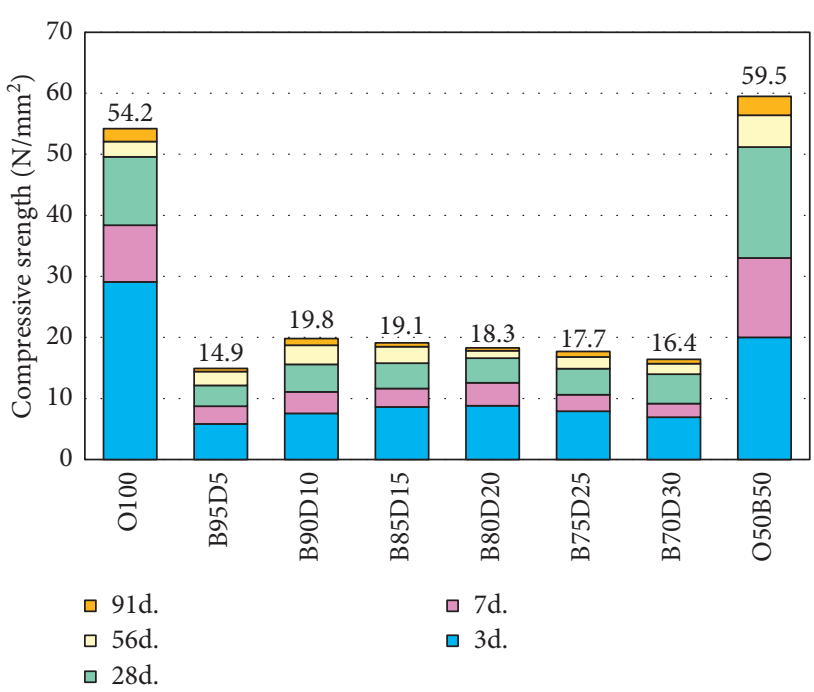

FIGURE 2: Compressive strength of alkali-activated mixes with BFS and DS.

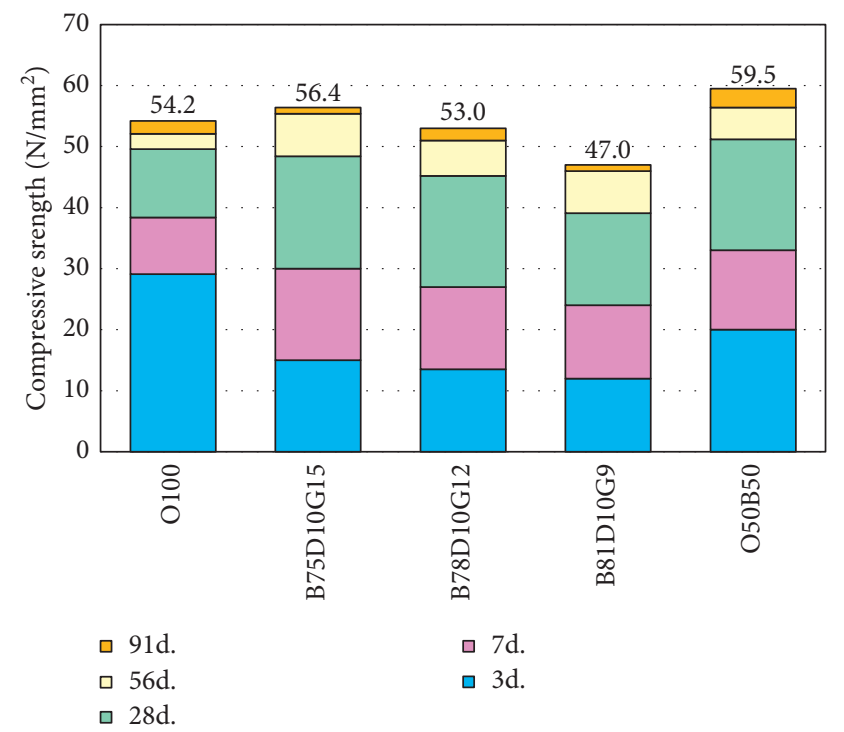

Figure 3: Compressive strength of alkali-activated mixes with BFS, DS, and G.

observed. In $\mathrm{O} 100$ and O50B50 samples, the $\mathrm{Ca}(\mathrm{OH})_{2}$ peak is approximately $18^{\circ}, 34^{\circ}, 47^{\circ}, 51^{\circ}$, and $54^{\circ}$, and the peak of the O50B50 sample is lower than that of O100 sample. The reason that the peak of the O50B50 sample is lower than the $\mathrm{O} 100$ sample is because the $\mathrm{Ca}(\mathrm{OH})_{2}$ produced from $\mathrm{OPC}$ is used and decreased owing to the latent hydration of BFS. The main hydrates of the $\mathrm{B} 80 \mathrm{D} 20$ sample were $\mathrm{Ca}(\mathrm{OH})_{2}$, graphite, $\mathrm{CaCO}_{3}$, and low-crystalline $\mathrm{C}-\mathrm{S}-\mathrm{H}$, while main hydrates of B75D10G15 were found as ettringite because $\mathrm{G}$ is mixed in the sample.

Figure 7 shows SEM images of O100, B80D20, and B75D10G15 samples after 28 days.

In the $\mathrm{O} 100$ sample, ettringite and C-S-H were observed. In B80D20, ettringite and flat-shaped calcium hydroxide were observed. In the B75D10G15 sample, a relatively large

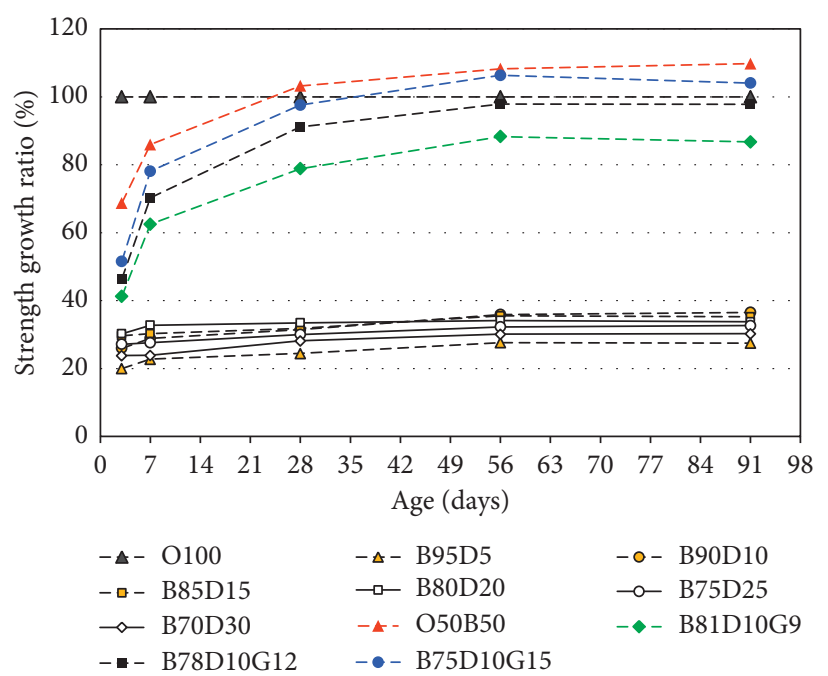

Figure 4: Compressive strength ratios by binder types.

amount of ettringite was observed compared to that of $\mathrm{O} 100$ and B80D20 samples.

3.5. Porosity. Figure 8(a) shows the cumulative porosity of O100, O50B50, B80D20, B81D10G9, B78D10G12, and B75D10G15 samples by using MIP. The cumulative porosities of O100, O50B50, B80D20, B81D10G9, B78D10G12, and B75D10G15 samples are 0.064, 0.081, 0.127, 0.154, 0.160, and $0.167 \mathrm{ml} / \mathrm{g}$, respectively. The cumulative porosity of the alkali-activated sample with BFS, DS, and G was larger than (239 to $261 \%$ ) that of the O100 sample. In addition, the higher the amount of $\mathrm{G}$, the higher the cumulative porosity. The cumulative porosity of the B80D20 sample was also higher than that of the O100 sample.

Figure 8 (b) shows the pore distribution characteristics of the total pores divided into three levels of 1 to $10 \mathrm{~nm}, 10$ to $100 \mathrm{~nm}$, and 100 to $10000 \mathrm{~nm}$. The ratio of the pore size of 10 to $100 \mathrm{~nm}$ of the total voids was 75 to $83 \%$. In the case of the pore size of 1 to $10 \mathrm{~nm}$, the porosity of the B80D20 sample was the highest at $1.12 \mathrm{ml} / \mathrm{g}$ and the porosity of the $\mathrm{O} 100$ sample was the lowest at $0.36 \mathrm{ml} / \mathrm{g}$. In the range of 10 to $100 \mathrm{~nm}$ pore size, the void contents of O100, O50B50, B80D20, B81D10G9, B78D10G12, and B75D10G15 samples were $2.43,2.98,4.34,4.51,4.82$, and $4.84 \mathrm{ml} / \mathrm{g}$, respectively. The porosity of the alkali-activated systems with BFS, DS, and $G$ was approximately 2 times higher than that of the O100 sample.

\section{Conclusions}

The following conclusions were obtained from the present investigation:

(1) DS contains $\mathrm{CaO}, \mathrm{SiO}_{2}, \mathrm{Fe}_{2} \mathrm{O}_{3}$, and $\mathrm{SO}_{3}$ and is composed of $\mathrm{Ca}(\mathrm{OH})_{2}$ and $2 \mathrm{CaO} \cdot \mathrm{SiO}_{2}$ as main compounds. Additionally, $\mathrm{SiO}_{2}$ and $\mathrm{Al}_{2} \mathrm{O}_{3}$ contents in DS are significantly lower than those in BFS, but it contains more $\mathrm{CaO}$ and $\mathrm{Fe}_{2} \mathrm{O}_{3}$ than BFS. 


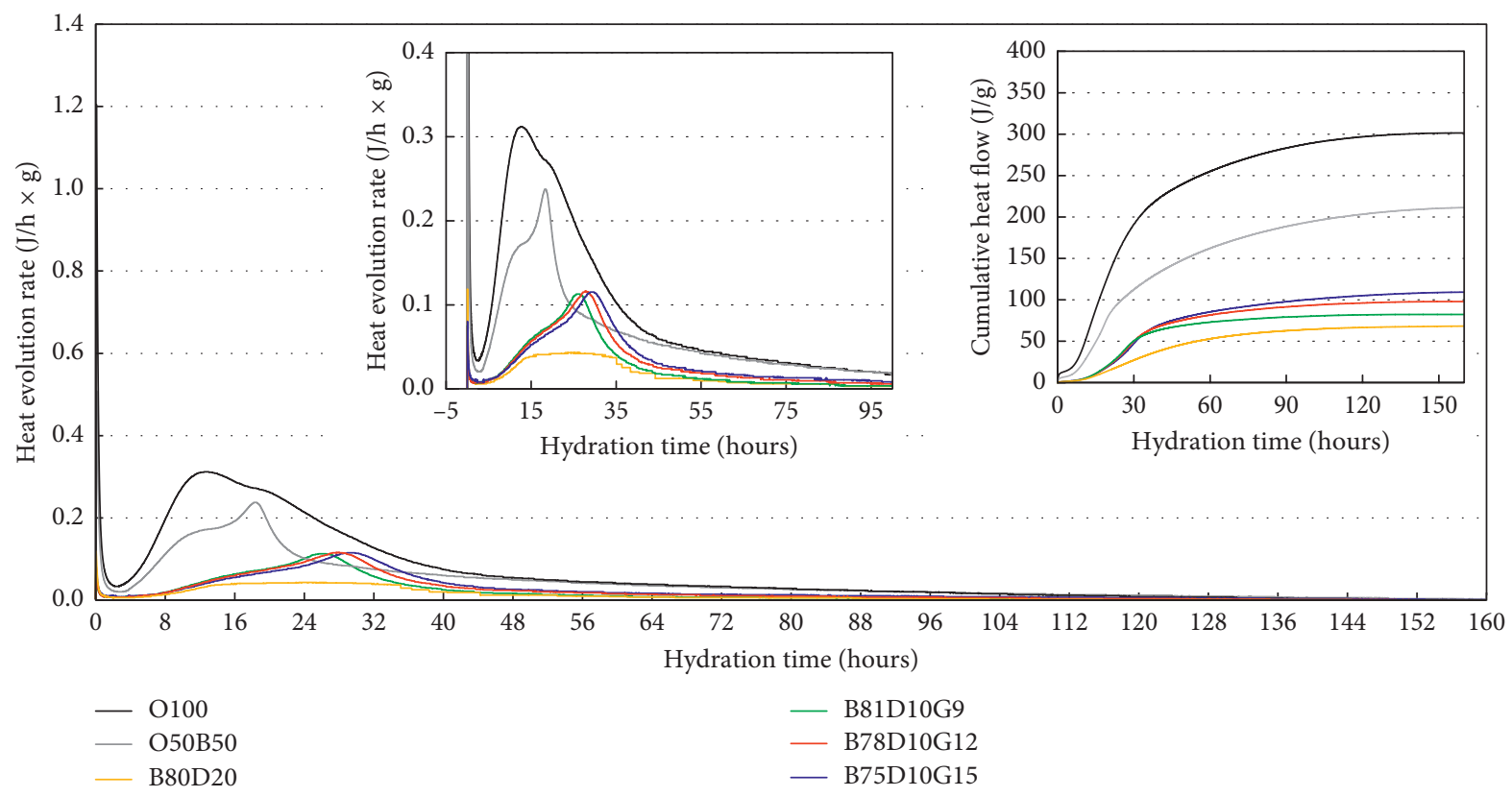

Figure 5: Hydration heat evolution.

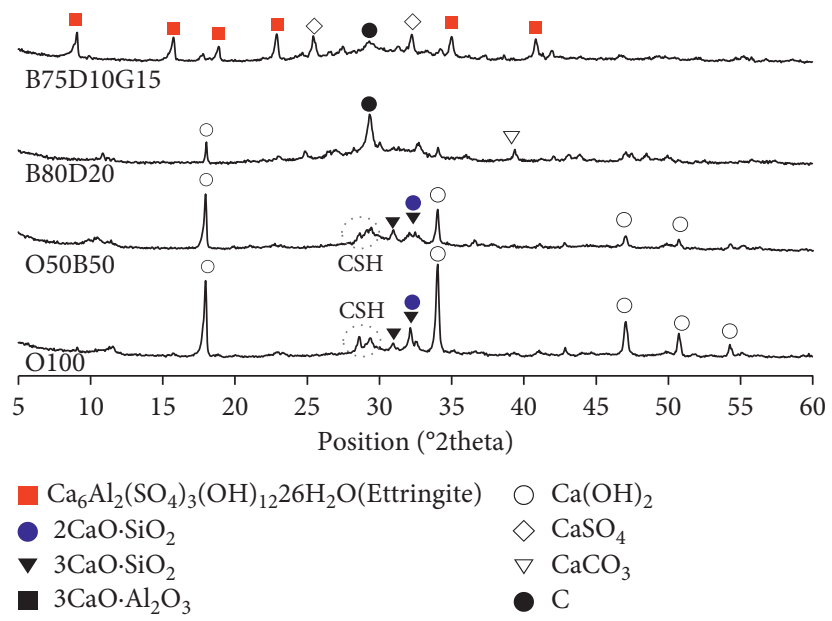

Figure 6: XRD spectra.

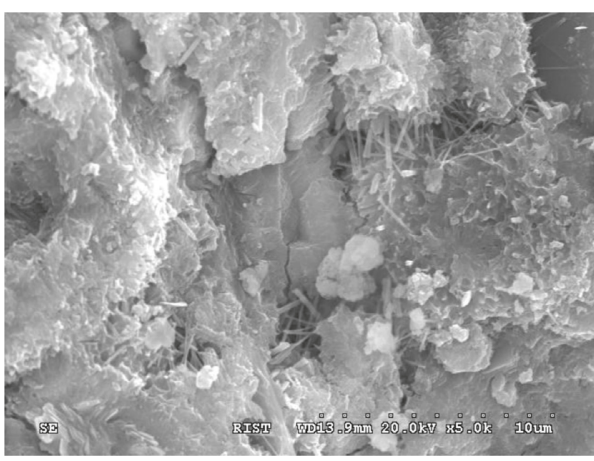

(a)

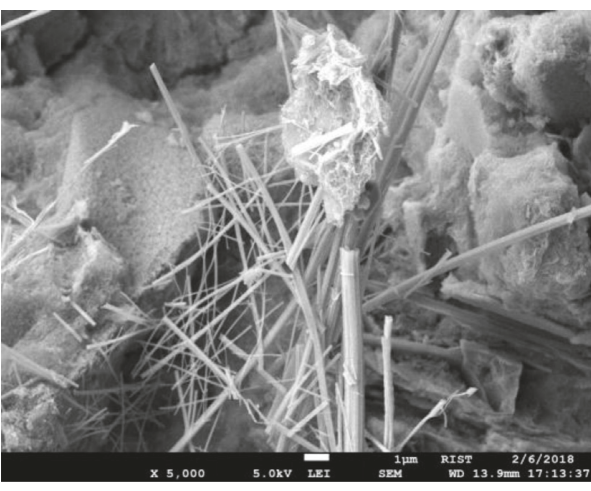

(b)

Figure 7: Continued. 


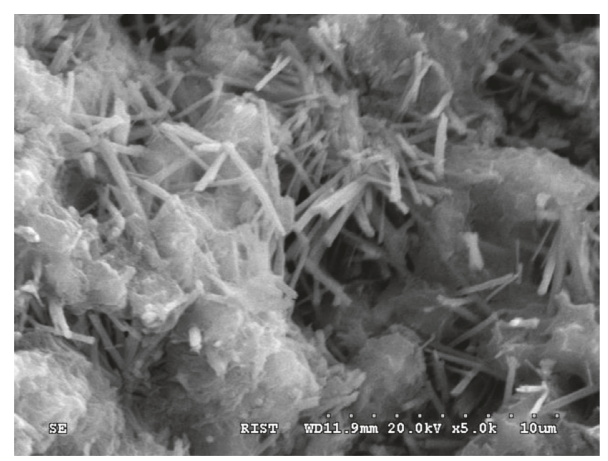

(c)

Figure 7: SEM images (x5000). (a) O100, (b) B80D20, and (c) B75D10G15.

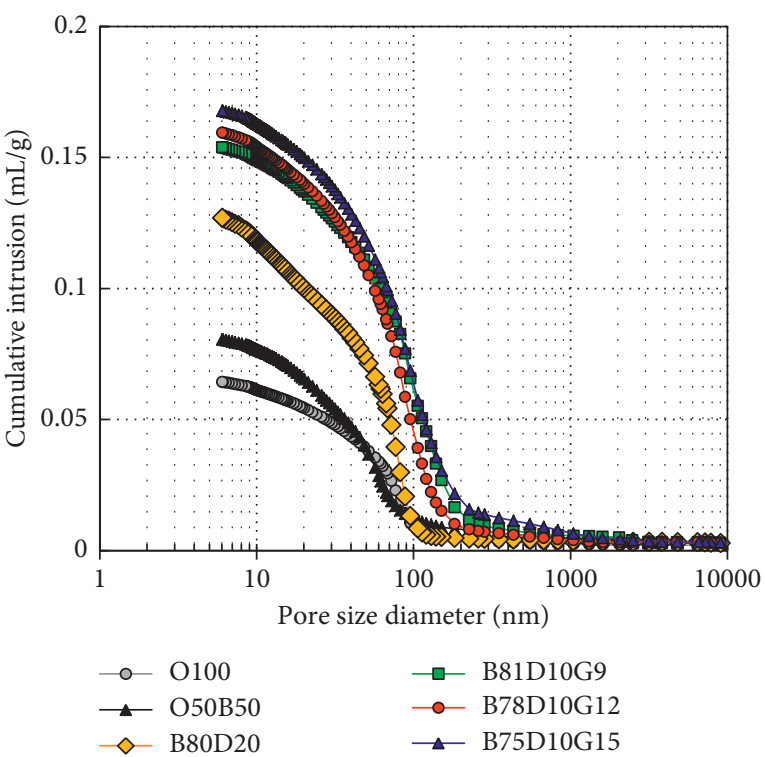

(a)

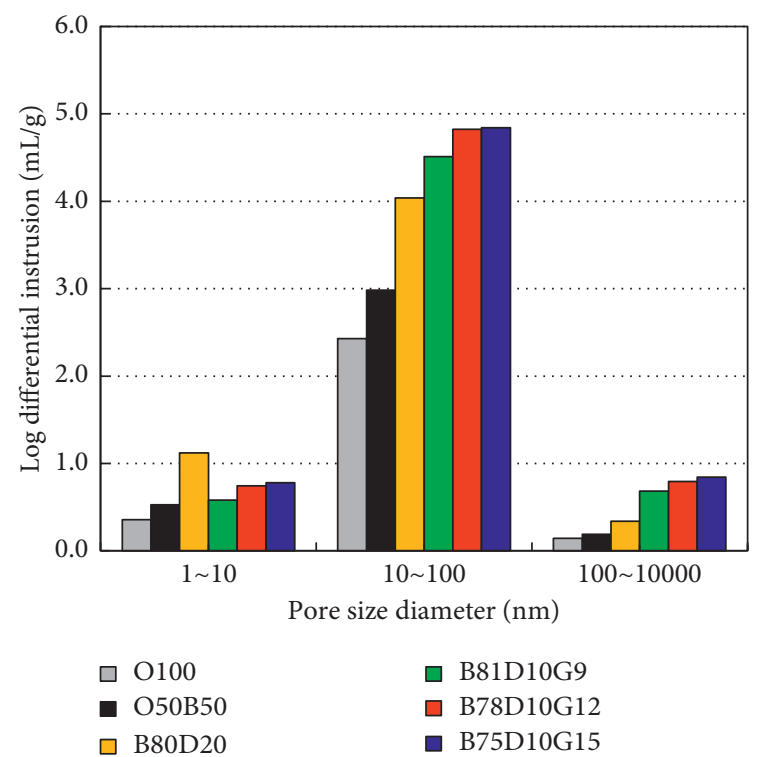

(b)

FIgURe 8: Porosity of samples by binder types. (a) Cumulative pore volume. (b) Distribution of pore size.

(2) The compressive strengths of the alkali-activated mixes with BFS and DS ranged from 14.9 MPa (B95D5) to $19.8 \mathrm{MPa}$ (B90D10) after 91 days. However, the 28 days compressive strengths of the alkali-activated mixes with BFS, DS, and G reached 39.1 MPa, 45.2 MPa, and 48.4 MPa, respectively, which were approximately 78.8 to $97.5 \%$ of that of O100 $\operatorname{mix}(49.6 \mathrm{MPa})$.

(3) The increase in compressive strength of the alkaliactivated mixes with BFS, DS, and G was noticeable until 28 days. The addition of $G$ to the alkaliactivated mixes with BFS and DS made it possible to increase the compressive strength by approximately 3 times compared to alkali-activated mixes consisting of BFS and DS only.

(4) The cumulative heat releases of O100, O50B50, B75D10G15, B78D10G12, B81D10G9, and B80D20 mixes were $301.4 \mathrm{~J} / \mathrm{g}(100 \%), 211.7 \mathrm{~J} / \mathrm{g} \quad(70.2 \%)$, $109.4 \mathrm{~J} / \mathrm{g}(36.3 \%), 97.9 \mathrm{~J} / \mathrm{g}(32.5 \%), 82.3 \mathrm{~J} / \mathrm{g}$ (27.3\%), and $69.1 \mathrm{~J} / \mathrm{g}(22.9 \%)$, respectively.
(5) The main hydrates of the B80D20 sample were $\mathrm{Ca}(\mathrm{OH})_{2}$, graphite, $\mathrm{CaCO}_{3}$, and low-crystalline C-S$\mathrm{H}$, while the main hydrates of B75D10G15 was found as ettringite because $G$ is mixed in the sample.

(6) The cumulative porosity of the alkali-activated sample with BFS, DS, and G was larger than (239 to $261 \%$ ) that of the $\mathrm{O} 100$ sample. In addition, the higher the amount of $\mathrm{G}$, the higher the cumulative porosity.

In addition, further studies are needed to establish the influence and relationships between the workability, strength and durability properties of alkali-activated systems, and the replacement ratio of DS and G.

\section{Data Availability}

The experimental investigation data used to support the findings of this study are available from the corresponding author upon request. 


\section{Conflicts of Interest}

The authors declare that they have no conflicts of interest.

\section{Acknowledgments}

This research was supported by Basic Science Research Program through the National Research Foundation of Korea (NRF) funded by the Ministry of Science and ICT (NRF-2017R1A2B4004053).

\section{References}

[1] X. Liu, G. Mao, J. Ren, R. Y. M. Li, J. Guo, and L. Zhang, "How might China achieve its 2020 emissions target? A scenario analysis of energy consumption and $\mathrm{CO}_{2}$ emissions using the system dynamics model," Journal of Cleaner Production, vol. 103, pp. 401-410, 2015.

[2] A. J. Moseson, D. E. Moseson, and M. W. Barsoum, "High volume limestone alkali-activated cement developed by design of experiment," Cement and Concrete Composites, vol. 34, no. 3, pp. 328-336, 2012.

[3] S.-H. Kim and J.-P. Hwang, "The $\mathrm{CO}_{2}$ emission in the process of cement manufacture depending on $\mathrm{CaO}$ content," Journal of the Korea Concrete Institute, vol. 25, no. 4, pp. 365-370, 2013.

[4] S. S. Wang, D. Q. Zhou, P. Zhou, and Q. W. Wang, " $\mathrm{CO}_{2}$ emissions, energy consumption and economic growth in China: a panel data analysis," Energy Policy, vol. 39, no. 9, pp. 4870-4875, 2011.

[5] I. Jakovljević, R. Mijailović, and P. Mirosavljević, "Carbon dioxide emission during the life cycle of turbofan aircraft," Energy, vol. 148, pp. 866-875, 2018.

[6] C. Shi, A. F. Jiménez, and A. Palomo, "New cements for the 21st century: the pursuit of an alternative to Portland cement," Cement and Concrete Research, vol. 41, no. 7, pp. 750-763, 2011.

[7] H. Douiri, S. Louati, S. Baklouti, M. Arous, and Z. Fakhfakh, "Structural, thermal and dielectric properties of phosphoric acid-based geopolymers with different amounts of $\mathrm{H}_{3} \mathrm{PO}_{4}$," Materials Letters, vol. 116, pp. 9-12, 2014.

[8] N. Essaidi, B. Samet, S. Baklouti, and S. Rossignol, "Feasibility of producing geopolymers from two different Tunisian clays before and after calcination at various temperatures," Applied Clay Science, vol. 88-89, pp. 221-227, 2014.

[9] P. Chindaprasirt, P. De Silva, K. Sagoe-Crentsil, and S. Hanjitsuwan, "Effect of $\mathrm{SiO}_{2}$ and $\mathrm{Al}_{2} \mathrm{O}_{3}$ on the setting and hardening of high calcium fly ash-based geopolymer systems," Journal of Materials Science, vol. 47, no. 12, pp. 1-8, 2012.

[10] K. Somna, C. Jaturapitakkul, P. Kajitvichyanukul, and P. Chindaprasirt, "NaOH-activated ground fly ash geopolymer cured at ambient temperature," Fuel, vol. 90, no. 6, pp. 2118-2124, 2011.

[11] R. S. Blissett and N. A. Rowson, "A review of the multicomponent utilisation of coal fly ash," Fuel, vol. 97, no. 7, pp. 1-23, 2012.

[12] M. Aboustait, T. Kim, M. T. Ley, and J. M. Davis, "Physical and chemical characteristics of fly ash using automated scanning electron microscopy," Construction and Building Materials, vol. 106, pp. 1-10, 2016.

[13] A. Cwirzen, R. Engblom, J. Punkki, and K. HabermehlCwirzen, "Effects of curing: comparison of optimised alkaliactivated PC-FA-BFS and PC concretes," Magazine of Concrete Research, vol. 66, no. 6, pp. 315-323, 2014.
[14] H. Bakkali, M. Ammari, and I. Frar, "NaOH alkali-activated class F fly ash: $\mathrm{NaOH}$ molarity, curing conditions and mass ratio effect," Journal of Materials and Environmental Science, vol. 7, no. 2, pp. 397-401, 2016.

[15] A. Motorwala, V. Shah, R. Kammula, P. Nannapaneni, and D. B. Raijiwala, "Alkali activated fly ash based geopolymer concrete," International Journal of Emerging Technology and Advanced Engineering, vol. 3, no. 1, pp. 159-166, 2013.

[16] R. P. Williams and A. van Riessen, "Determination of the reactive component of fly ashes for geopolymer production using XRF and XRD," Fuel, vol. 89, no. 12, pp. 3683-3692, 2010.

[17] G. Görhan and G. Kürklü, "The influence of the $\mathrm{NaOH}$ solution on the properties of the fly ash-based geopolymer mortar cured at different temperatures," Composites Part B: Engineering, vol. 58, pp. 371-377, 2014.

[18] S. A. Bernal, J. L. Provis, B. Walkley et al., "Gel nanostructure in alkali-activated binders based on slag and fly ash, and effects of accelerated carbonation," Cement and Concrete Research, vol. 53, pp. 127-144, 2013.

[19] J. L. Provis, R. J. Myers, C. E. White, V. Rose, and J. S. J. van Deventer, "X-ray microtomography shows pore structure and tortuosity in alkali-activated binders," Cement and Concrete Research, vol. 42, no. 6, pp. 855-864, 2012.

[20] Q. L. Li, M. Z. Chen, F. Liu, S. P. Wu, and Y. Sang, "Effect of superfine blast furnace slag powder on properties of cement based materials," Materials Research Innovations, vol. 19, pp. S1-168-S1-171, 2015.

[21] A. Bouaziz, R. Hamzaoui, S. Guessasma, R. Lakhal, D. Achoura, and N. Leklou, "Efficiency of high energy over conventional milling of granulated blast furnace slag powder to improve mechanical performance of slag cement paste," Powder Technology, vol. 308, pp. 37-46, 2016.

[22] H. Yazıcı, M. Y. Yardımc1, H. Yigiter, S. Aydın, and S. Turkel, "Mechanical properties of reactive powder concrete containing high volumes of ground granulated blast furnace slag," Cement and Concrete Composites, vol. 32, no. 6, pp. 639-648, 2010.

[23] S. Lee, A. van Riessen, C.-M. Chon, N.-H. Kang, H.-T. Jou, and Y.-J. Kim, "Impact of activator type on the immobilisation of lead in fly ash-based geopolymer," Journal of Hazardous Materials, vol. 305, pp. 59-66, 2016.

[24] P. S. Deb, P. K. Sarker, and S. Barbhuiya, "Effects of nanosilica on the strength development of geopolymer cured at room temperature," Construction and Building Materials, vol. 101, pp. 675-683, 2015.

[25] W.-T. Kuo and T.-C. Hou, "Engineering properties of alkaliactivated binders by use of desulfurization slag and GGBFS," Construction and Building Materials, vol. 66, pp. 229-234, 2014.

[26] W.-T. Kuo, H.-Y. Wang, and C.-Y. Shu, "Engineering properties of cementless concrete produced from GGBFS and recycled desulfurization slag," Construction and Building Materials, vol. 63, pp. 189-196, 2014.

[27] ASTM International: ASTM C349, Standard Test Method for Compressive Strength of Hydraulic-Cement Mortars (Using Portions of Prisms Broken in Flexure), ASTM International, West Conshohocken, PA, USA, 2008.

[28] A. Mladenovič, B. Mirtič, A. Meden, and V. Z. Serjun, "Calcium aluminate rich secondary stainless steel slag as a supplementary cementitious material," Construction and Building Materials, vol. 116, pp. 216-225, 2016.

[29] H. L. Ritter and L. C. Erich, "Pore size distribution in porous materials," Analytical Chemistry, vol. 20, no. 7, pp. 665-670, 1948. 
[30] E. Özbay, M. Erdemir, and H. İ. Durmuş, "Utilization and efficiency of ground granulated blast furnace slag on concrete properties-a review," Construction and Building Materials, vol. 105, pp. 423-434, 2016.

[31] D. Bondar, C. J. Lynsdale, N. B. Milestone, N. Hassani, and A. A. Ramezanianpour, "Effect of type, form, and dosage of activators on strength of alkali-activated natural pozzolans," Cement and Concrete Composites, vol. 33, no. 2, pp. 251-260, 2011.

[32] S. Liu and L. Li, "Influence of fineness on the cementitious properties of steel slag," Journal of Thermal Analysis and Calorimetry, vol. 117, no. 2, pp. 629-634, 2014.

[33] K.-H. Yang, A.-R. Cho, J.-K. Song, and S.-H. Nam, "Hydration products and strength development of calcium hydroxide-based alkali-activated slag mortars," Construction and Building Materials, vol. 29, pp. 410-419, 2012.

[34] B. Cho, "Hydration characteristics of cement-free binder using Kambara reactor slag," Magazine of Concrete Research, vol. 68, no. 22, pp. 1143-1154, 2016.

[35] Y. Jeong, J. E. Oh, Y. B. Jun, J. N. Park, J. H. Ha, and S. G. Shon, "Influence of four additional activators on hydrated-lime $\left[\mathrm{Ca}(\mathrm{OH})_{2}\right]$ activated ground granulated blastfurnace slag," Cement and Concrete Composites, vol. 65, no. 1-10, 2016.

[36] A. Hadj-sadok, S. Kenai, L. Courard, and A. Darimont, "Microstructure and durability of mortars modified with medium active blast furnace slag," Construction and Building Materials, vol. 25, no. 2, pp. 1018-1025, 2011.

[37] H. Jin, "Late-Age properties of concrete with different binders cured under $45^{\circ} \mathrm{C}$ at early ages," Advances in Materials Science and Engineering, vol. 2017, Article ID 8425718, 13 pages, 2017.

[38] B. Cho and H. Choi, "Physical and chemical properties of concrete using GGBFS-KR slag-gypsum binder," Construction and Building Materials, vol. 123, pp. 436-443, 2016.

[39] P. Sharmila and G. Dhinakaran, "Compressive strength, porosity and sorptivity of ultra fine slag based high strength concrete," Construction and Building Materials, vol. 120, pp. 48-53, 2016.

[40] A. Hadjsadok, S. Kenai, L. Courard, F. Michel, and J. Khatib, "Durability of mortar and concretes containing slag with low hydraulic activity," Cement and Concrete Composites, vol. 34, no. 5, pp. 671-677, 2012.

[41] J. Hu, "Comparison between the effects of superfine steel slag and superfine phosphorus slag on the long-term performances and durability of concrete," Journal of Thermal Analysis and Calorimetry, vol. 128, no. 3, pp. 1251-1263, 2017. 


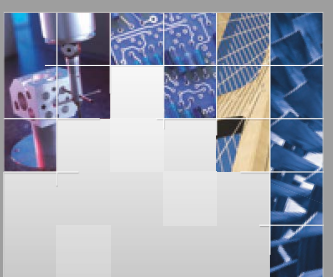

\section{Enfincering}
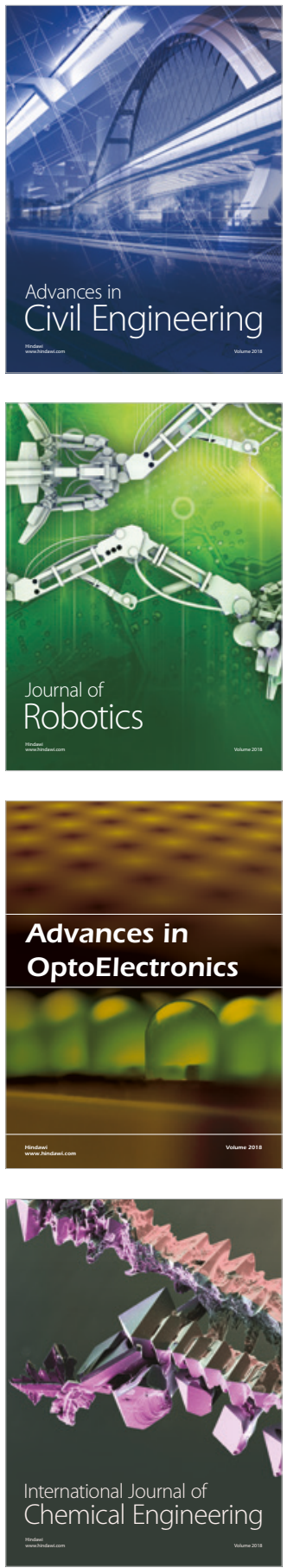

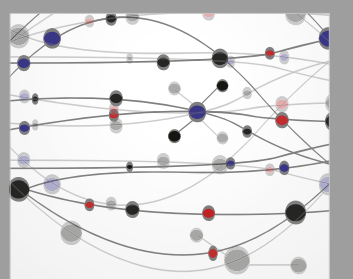

\section{Rotating \\ Machinery}

The Scientific World Journal

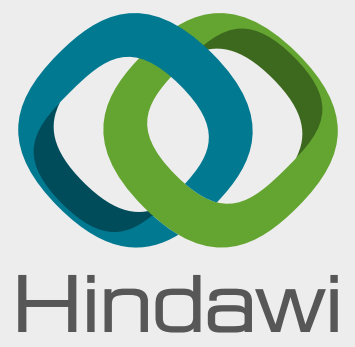

Submit your manuscripts at

www.hindawi.com
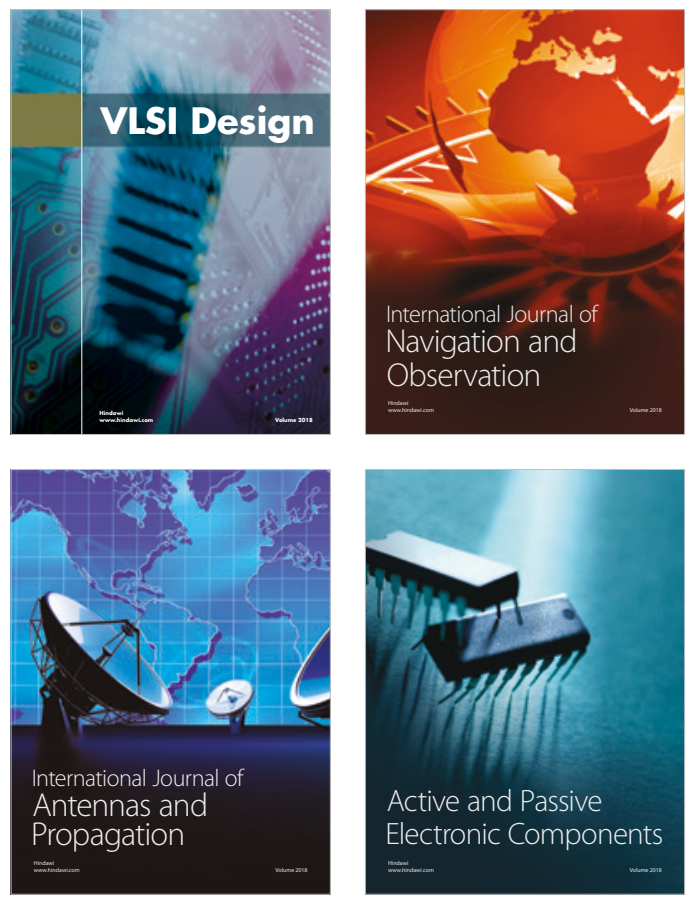
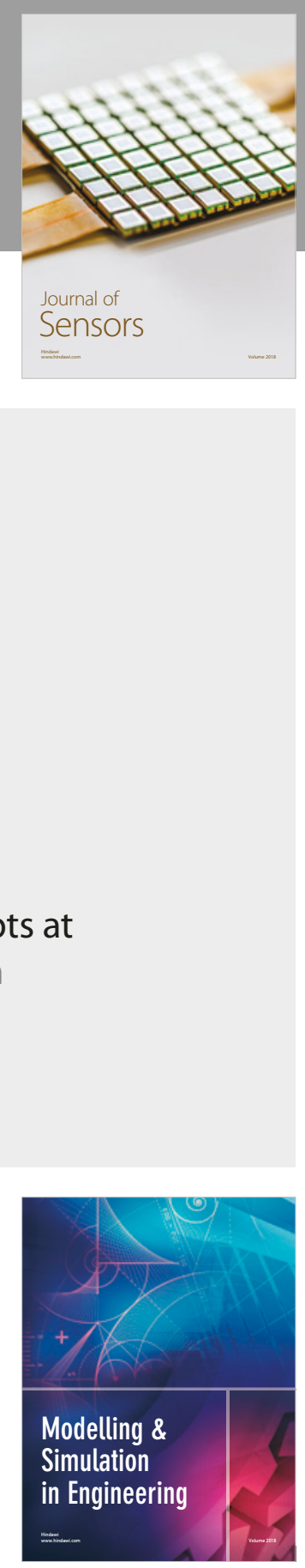

\section{Advances \\ Multimedia}
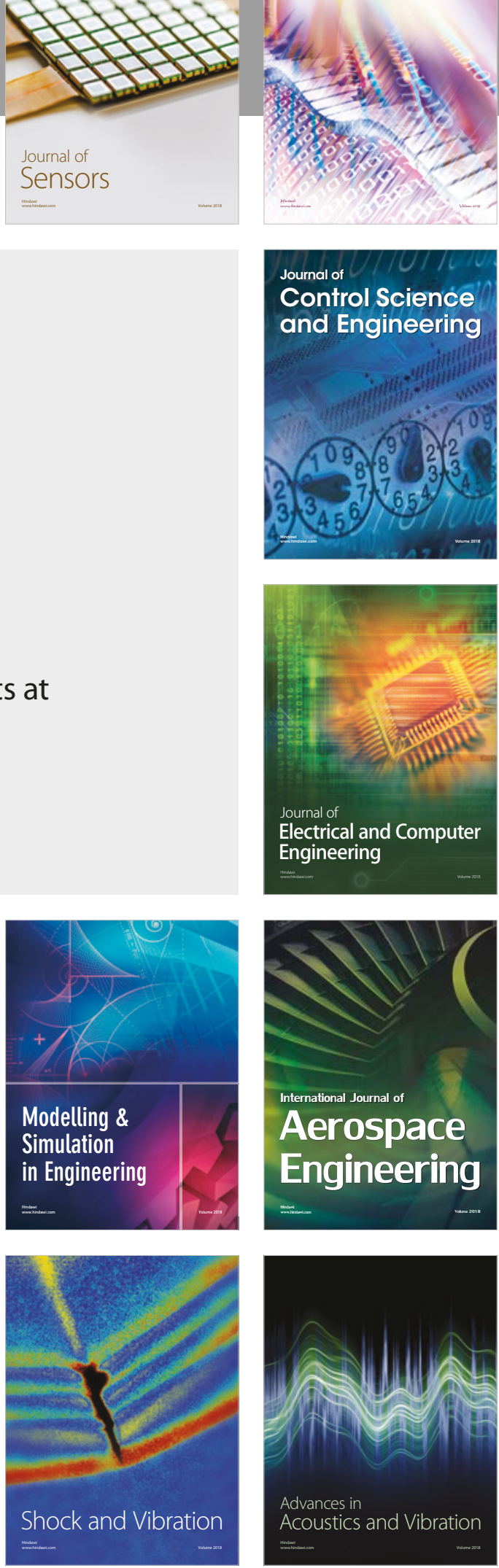